Variations sur la lettre, le mètre et la mesure :

Shakespeare

\title{
Taking the measure of The Tempest: The Diviners and Mama Day
}

\section{Ruth Morse}

\section{(2) OpenEdition Journals}

Electronic version

URL: http://journals.openedition.org/shakespeare/967

DOI: 10.4000/shakespeare.967

ISSN: 2271-6424

Publisher

Société Française Shakespeare

\section{Printed version}

Date of publication: 1 November 1996

Number of pages: $41-54$

\section{Electronic reference}

Ruth Morse, "Taking the measure of The Tempest: The Diviners and Mama Day », Actes des congrès de la Société française Shakespeare [Online], 14 | 1996, Online since 01 January 2007, connection on 03 May 2019. URL : http://journals.openedition.org/shakespeare/967 ; DOI : 10.4000/shakespeare.967 


\section{Variations sur la lettre,}

le mètre et la mesure

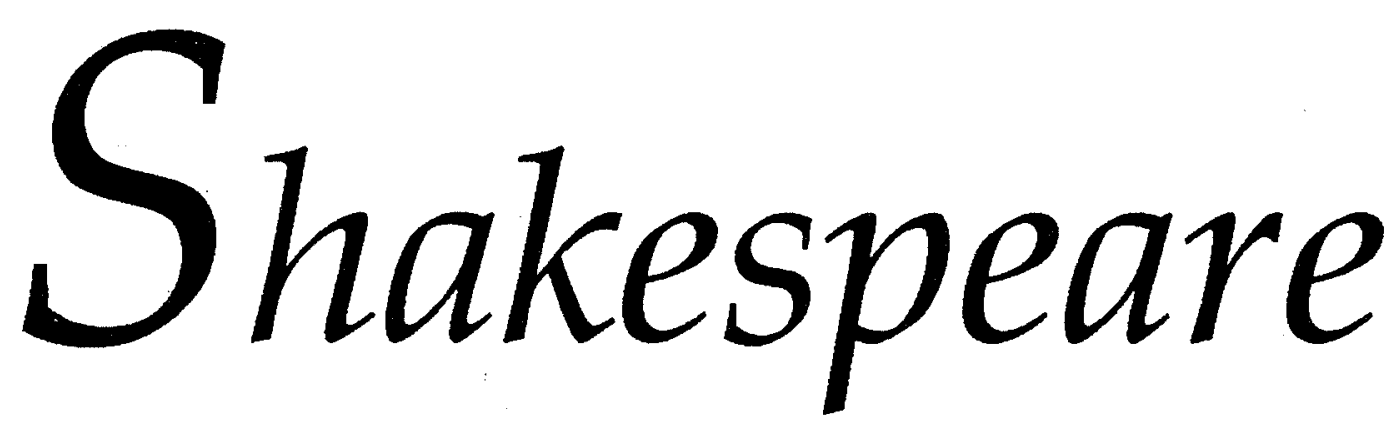

textes présentés par Dominique Goy-Blanquet

Directeur de la publication : Richard Marienstras 


\section{Taking the measure of The Tempest : The Diviners and Mama Day}

The Tempest has been one of Shakespeare's most adapted plays. Its stage history is concomitantly a history of the British theatre, from pantomime to opera ${ }^{1}$. It has had other lives, too, from its position in romantic ideas of Shakespeare's biography and his so-called farewell to the stage, to a supporting role as witness for the nineteenth-century Darwinians' idea of the missing link, to a veritable efflorescence of walk-on parts, cameos, and star vehicles in twentieth-century psychoanalytic and social arguments about European expansion ${ }^{2}$. The play has given us individual poems and paintings, not to speak of screen-plays for three film adaptations. It has been an inspiration for writers of science fiction ${ }^{3}$. One might argue that this lineage resonates - because of its setting on a desert, that is, deserted, uncivilized, isle with its counterpoint between magic and materialism, even as far, or as thin, as to brush in passing Defoe's castaway in Robinson Crusoe and Hawthorne's outcast in The Scarlet Letter. For descent lines must include the changes introduced by subsequent interpretations, although the branch of the family sired by the desert island may suggest only a faint family resemblance between Prospero and Dr Moreau. From Afro-Caribbean authors aghast at Francophone psychoanalytic appropriations of a posited colonial relationship, to "old" settler-colony triumphalism over their brave new worlds, The Tempest has served as an icon in arguments over coming, seeing, and conquering. This is as true for Hispanic America as for the Anglophone north, from the first-contact theme in science fiction to the revolt of the oppressed. For example, the Hispanic tradition of assigning strong allegorical interpretations to different figures in a text, from Don Quixote to the present, in which the integrity of the source text, or its historical position, are relatively unimportant. So the shift, in Hispanic cultural debate, from the idea of South America as an Ariel to an insistent Calibanic liberation ${ }^{4}$. These have often, like the psychoanalytic return of the repressed, manifested precisely, but, of course, in reverse, the terms and conditions set by the Masters of the Universe.

In recent years The Tempest has inspired a number of women writers in a series of novels which have returned to the nameless island in search of more meanings and possibilities, some of which turn out to be familiar stories of poetic inspiration and the authority to speak, but may nonetheless have a satisfying obliquity, and originality, in their use of Shakespeare's play. For The Tempest has never been all things to all readers - or writers - however much it has changed as the world has changed. Certain constants can be discerned across the dozens of interpretations available. The "measure" that my authors take is not only their assessment of The Tempest, it is their fundamental recognition that measure itself is 
the heart of the matter ${ }^{5}$. It is a measure of their measure that the quality of their reading should bring us back to the play fresh. And the quality of their reading also provides a test for how much we attribute to the changed world, and how much to their individual points of view. What their readings of The Tempest have in common is a shared exploration of power, poetry, and balance which is true to our experience of the play, but also true to other recent interpretations of it ${ }^{6}$. Unlike many recent literary critics, they do not focus on Shakespeare's alleged racism or misogyny, or his influence upon or implication in ideologies of conquest and dominance. In writing their own novels, as part of their own work and their own concerns, they are engaged in that intertextuality which absorbs and transforms the past. Reading them reading Shakespeare will, I hope, help us read them all better. They are not sticks - or staffs - with which to beat the Bard.

Throughout Shakespeare's work one central evaluative-descriptive sense of "measure" implies that measure is right or correct, what we might otherwise describe as "just proportion"7. Measure, in this Aristotelian sense of moderation, embodies balance, peace and harmony, as it had throughout the Middle Ages, when individuals loving "out of measure" or anger "passing measure", as we read in Malory, could bring human society caving in upon itself. To control others, as his characters find, one must first control oneself, not as a desert island, but as part of the continent of humanity, as at five hundred years' distance Auden's Antonio so aptly illustrates by his denial ${ }^{8}$. Balance is seldom, and then neither easily, nor for long, achieved, as play after play tells us, yet it is what we seek. Disruption is cheap, and easily available. When we seek just proportion, life in measure, it is in order to bring ourselves into harmony not only with the rest of the human continent, but with God's universe. In this, if not in a more narrowly autobiographical sense, the artist as makar participates in the mystery of creation : the action, in this sense, imitates and praises a greater Creator.

There is a trivial sense in which getting everything in the right place is not much more than George Herbert's tidying a room. Yet there are parallelisms between one's surroundings, one's self, and one's nearest and dearest which make the proper running of a household an allegory not only for human government, but for the immanence of the Divine on earth. This insight is at the heart of the compliment which Milton pays to the Duke of Bridgewater in Comus (whose eponymous villain owes something to Caliban), for government of the household, including the right upbringing of one's children, is a sign or token of godliness which radiates out to underwrite other masteries. This is why explorations of "measure" remained for so long related to music and dancing, which participate in the harmonies of the planets, as well as to their description through mathematics, in that combination of music and number which lies at the heart of poetry. These relations had been part of western philosophical poetry since well before Boethius, but the De Consolatione, translated by Chaucer as by Queen Elizabeth, provided a locus classicus of reference. At their heart is love.

Because "measure" implies "right measure", the commitment to creation and love implies even more than the right-mindedness which does, indeed, praise the Creator. It distances participants from evil, it assumes the perception of wrong- 
doing as perversion of the creative power. To do ill, to summon up darker powers to wreak havoc, to assist the destruction of other people which comes with seducing them from their own search for just proportion, is already a betrayal of measure, as it betrays the trust which is love's gift. White magic or medicine, which help the Creator along, are thus far from that dabbling in the demonic which damned Faust, or rolled Sycorax into a hoop. When Prospero resigns his revenge for reconciliation, when he puts his house in order, he escapes, among other things, the consequences of moral, artistic, and human ugliness which otherwise brought him too close for comfort to the witch of Argiers, or Colchis. Measure is not mentioned in The Tempest, and yet the play is informed by questions of power, love, balance, good government, domination, betrayal, which are explored in terms of self, family, household, kingdom. From the sailor's profound "What cares these roarers for the name of king ?" to Miranda's discovery, at chess, that Ferdinand will cheat even her, the play repeats the heart of the matter.

Under-informed authors tend to use- this play as a cultural convenience. Books such as Phyllis Gottleib's O Master Caliban or Stephen Popkes'Caliban Landing seize upon the idea of the subjection of Caliban to create a free satellite from the ideas that there may be other forms of being, or that our robot-servants may rebel, but these are pretexts, using their Shakespearean allusion almost decoratively. Although they mark the trajectory of cultural icons freeing themselves from their original orbits, they change neither the emphasis in our understanding of Shakespeare nor in themselves. Authors have neither to have read the play nor to have any historical sense of Shakespeare in his times. The elevation of Caliban is a case in point.

We may notice in passing that these second-order interpretative stereotypes are part of larger issues of reading. One of the forces behind the shift perceptible between the editions of the play by Kermode and Orgel is precisely the question of the play and the New World aboriginals which is so excitingly, if ahistorically, explored by creative writers from Césaire to Lamming to Warner ${ }^{9}$. It would be a categorical error to take a fashionable interpretation, however ahistorical, as a sign of lack, even failure, when a modern writer emphatically helps him- or her-self to one piece of the whole design without engaging with the whole or attempting to understand the context. Nevertheless, it seems only human that in judging the inadequacies of a modern text, we take its misjudgements about, or apparent misuse of, its intertext, as one more offence to be taken into consideration. There is no need to call out the interpretation police.

It is, therefore, even more urgent than usual to get one's categories of critical assessment clear. One is prone not only to project one's own ideas of a "correct" interpretation onto a relatively new fiction, but also to find it in Shakespeare's. Political arguments are then reinforced by the degree of correctness of their analysis of Shakespeare. The Green Bard who is currently emerging is a fine example of present-mindedness legitimated by reference to a new reading, who may give rise to interpretations as exciting as those of the Colonialist Bard of the last fifty years ${ }^{10}$. The nexus of arguments here is complex, for it refers not only to possible interpretations of Renaissance texts, but to those texts' implication in or respon- 
sibility for certain social injustices (always these), as well as the response of social institutions to the further centralizing of the texts. In what follows I shall broach some of these issues by analyzing the intertextuality of two novels of the last twenty years which explicitly use The Tempest.

The Diviners was Margaret Laurence's fifth and final novel in the series set in Manawaka, the fictional Canadian town invented on the pattern of her own Neepawa, in Manitoba, where she was born in $1926^{11}$. It was also her last book for adults. In the twenty-five years since its publication it has assumed a celebrated centrality and importance in Canadian literature, for while, on the personal level, it reads as a bildungsroman which is also a kunstlerroman, it has come to be read politically as an allegory for Canada itself. It is deeply attached to The Tempest, a book which Laurence had already used in her African fiction, where the naiveté of the heroine of This Side Jordan, Miranda Kestoe, wreaks a certain amount of havoc, but the author asserts a kind of optimism about a brave new Gold Coast which - as she, and others, have subsequently recognized - was to be severely disappointed in the succeeding history of Ghana. In that early book one finds a recycling of "incidents" - names, details, lines from the play - which is part of what might be called the catalogue-approach to intertextuality. This is not for a moment to say that making lists of equivalences is trivial, but that in a certain sense it can be a way of attending to the accidents of a book rather than its substance. In my discussion of the later novel I shall begin with Laurence's transmutation of one substantial problem suggested by her reading of The Tempest, then use The Diviners to refocus our attention to Shakespeare.

At the height of her powers, Laurence recapitulated some of the concerns of the African novel in The Diviners of 1974, invoking Shakespeare explicitly at a number of points. The Diviners takes its narrator up to the point at which she is ready to begin the novel we have just read; in the course of it she writes a number of other novels, based on her own life, or the lives of the people she has known, including one which reinterprets The Tempest. She describes this novel in a letter to a friend,

It's done in semi-allegorical form, and also it has certain parallels with The Tempest. Maybe I'm an idiot to try this, but it's the form the thing seems to demand, so I've quit fighting it. I've got the first draft nearly done now, so don't mind saying a bit about it, although it'll take a lot of rewriting. It's called Prospero's Child, she being the young woman who marries His Excellency, the Governor of some island in some ocean very far south, and who virtually worships him and then who has to go to the opposite extreme and reject nearly everything about him, at least for a time, in order to become her own person. It's as much the story of H.E. I've always wondered if Prospero really would be able to give up his magical advantages once and for all, as he intends to do at the end of The Tempest. That incredibly moving statement - "What 
strength I have's mine own, Which is most faint - " [sic]. If only he can hang onto that knowledge, that would be true strength. And the recognition that his real enemy is despair within, and that he stands in need of grace, like everyone else - Shakespeare did know just about everything. I know it's presumptuous of me to try to put this into some different and contemporary framework and relevance, but I can't help it. Well, hell, maybe it's not so presumptuous as that. (p. 330)

Presumptuous, perhaps, for Morag Gunn, the narrating author of The Diviners, but not for Laurence. Authority, legitimacy, and exemplarity suffuse Laurence's work. Like Whitman or Faulkner before her, her autobiographical or self-referential writing is the egotism which claims the self as allegory, as type, and as nation. She is a woman asking who has the word, and in what language; concerned about power and love; recreating history as a series of stories all of which may be true; hoping against experience for an undefined reconciliation in a future generation - these are the themes Laurence has located in The Tempest which have concerned her own work for over a decade, and which here become also questions about Canada's past and future. For Laurence, Caliban represents the problem of poetry, of ownership of the past and future, and the way the problem is defined constitutes who Caliban is.

Because The Diviners is the complex novel it is, identification of one theme involves the others. Though one must equally be aware that to use the name Caliban to represent a theme may occlude as well. Laurence's Calibanic theme is among other things a complicated vision of male power, particularly male control of the word. The plot reveals aspects of character, and character reveals the problem in all its variety, not once but repeatedly. Each of the novel's important male characters aspires to some kind of artistic representation, from folklore stories to poetry to song to painting, and each of them is limited by his failure to connect. Two of them have learned to curse. But in order to follow the abstract question one must take cognizance of the synchronicity of Morag's own generation at the same time as her place - and Canada's - in history keeps diachronicity before us.

At the heart of The Diviners lies a question which is articulated as a twosuitor plot, embedded in the problem of inheritance. One may choose one's lover, but what about one's father? and what happens when the lover represents a choice of ancestry ? Both Morag's "suitors"' are right, both are wrong. Morag's natural father is dead, and she is raised by Christie Logan, a Scotsman who has emigrated to Canada, who fought beside her father in the Flanders trenches, and who returns to Manawaka to become the town scavenger. There is a wife, but like Mrs. Prospero, she is almost completely erased. In the progenitors and lovers we see the problem of who speaks, and who, in speaking, owns the past. "What a piece of work is man. Who said that ? Some brain," Christie says at one point (p. 88). This quotation is followed by the narrative of Bourlon wood, the Great War battle in which Morag's father saved Christie's life. It is Christie who identifies the difficulty of writing their past : "Well, d'you see, it was like the book says, but it wasn't like that, also. That is the strangeness" (p. 90). There is a point here about common 
people and inarticulateness, a paradox about the eloquence of the ineloquent. The larger point, about the truth/falseness of writing is more obvious, but not more important :

Morag had once tried divining with the willow wand. Nothing at all had happened. Royland had said she didn't have the gift. She wasn't surprised. Her area was elsewhere. He was divining for water. What in hell was she divining for? You couldn't doubt the value of water. (p. 102)

Morag marries her English, but India-born, professor of English, who helps her educate herself, but insists upon keeping her as his innocent Miranda, a childbride to whom he denies autonomy as well as children. That Brooke Skelton, with his allegorical name, is also a reminder of Empire, is obvious, and his role as the nurturing but stifling inheritance is almost too much so. He saves Morag from a number of decisions, such as earning a living, or returning to her own original place and social class, and supports her while she secretly becomes a writer and puts herself into the position of assuming independence. Her first lover, he is also her third father, representing England, high culture, legitimacy, and the failure to live and change. As she becomes more dissatisfied with their marriage the references to Prospero's power become explicit :

Now, and somewhat oddly, considering the awfulness of the house on Hill Street, the apartment in Toronto seems more than ever like a desert island, or perhaps a cave, a welllighted and beautifully appointed cave, but a cave just the same. (p. 254)

The other wrong right lover is Jules Tonnerre, a métis from Manawaka with whom Morag could never live (and who would not wish to live permanently with her), but who provides her with the child she so much desires. If there are aspects of Prospero in Brooke, Jules invites us to think of Caliban, not in himself as a character, but in his own historical-familial relationship to his inarticulate father, the allegorically-named Lazarus. The English/Scottish settlers (Morag's natural father, Christie, Brooke) seized the land from the métis; in some way salvation depends upon a recuperation of that inheritance, a righting of an ancient wrong through a betrothal between Milan and Naples. It is in such multi-dimensional complexities that we see what lifts the novel beyond catalogue or simple questions; Laurence reimagines the problematique inherent in Shakespeare's characters : articulateness, tradition, and poetry. It is as if we saw Miranda take Prospero's place on an island of her own choosing, and Miranda's child emerge from both Caliban and Ariel.

Prospero taught Caliban to speak. It is common to say that before Naples arrived, the island had no language, although we never hear of anyone teaching Ariel. Morag's men are haunted not by finding a voice, as Morag is, but by losing one. Jules, who is a singer-songwriter, and therefore a poet, has nonetheless lost not 
one but two languages, both the French and the Cree which are the birthright of his mixed blood; Christie has lost the Gaelic and is emphatically inarticulate in English, except when he is telling stories of Scotland's and Canada's Indian wars. When Morag, in the course of her sojourn in Britain, discusses the problem with her Scottish lover, she finds that

He [Dan McRaith] didn't have a word of the Gaelic himself, or perhaps a few words here and there, but nothing to speak of, nothing to speak with. Why not take lessons, then, he had said. She hadn't, of course. Too lazy. She would have liked to gain the speech by magical means, no doubt. Yet it seemed a bad thing to have lost a language. Talking to one or two old fishermen in Crombruach, those years ago, she'd realized that. They spoke a mellifluous English, carefully, as though translating into it in their heads, and some of their remarks were obscure to her, but they would never explain, or could not.

Christie, telling the old tales in his only speech, English, with hardly any trace of a Scots accent, and yet with echoes in his voice that went back and back. Christie, summoning up the ghosts of those who had never been and yet would always be.

The lost languages, forever lurking somewhere inside the ventricles of the hearts of those who had lost them. Jules, with two languages lost, retaining only broken fragments of both French and Cree, and yet speaking English as though forever it must be a foreign tongue to him. (p. 244)

These men are all doomed, although the skeletal Brooke Skelton is a successful university teacher. Alcohol and ill-health, class-thwarted ambition, personal obstinacy and historical bad luck inhibit the men from genuinely attaching themselves to other human beings. And, alas, they all depend upon the dependency of their women.

If there is a male character who appears to combine the serene assurance, even the magic of The Tempest, it is Morag's friend Royland, the water Diviner, who makes the most explicit reference to the book's title - but even he turns out to have abused his power and, in an earlier part of his life, to have driven his wife to suicide. Royland's sensitivity with a willow wand is one of the accidents which create an equivalent for Prospero's magic, but his gift at finding water is no more, if no less, magical than the song-, novel-, or poetry-writing of the other characters. Humility and one's own strength appear to include the strength to live single, with one's child, and for one's art. Balance is always precarious, and knowing what is right never guarantees one's ability to do it, to say it.

IfThe Diviners is a central novel for Canadians, Morag's personal odyssey is also a national history, which finds, in its descriptions of one woman's experience, a way of recapitulating history. England and Scotland, French and Indian, combine, per impossibile, in Laurence's idea of what it is to be Canada. From Morag's earliest 
stories of Piper Gunn she concentrates on his wife and her daughter, so the idea of woman as subject is there from the start. Tests of ethnic reversal for Morag, with Scots against English, suggest for Laurence always the possibility that the real aristocrats are the métis, the men to whom the land belonged, and who have been dispossessed of both land and language. Canada's odyssey is to move from being a colony to being a country, by virtue of finding one's own voice. In this sense Morag Gunn herself becomes a kind of Prospero, making her house an island in which she finds her balance, but from which her own daughter moves out to struggle with the same choices, the same impossibilities. This has been well described by Gayle Greene :

The "use" of memory, then, is liberation. So also is the use of the literary tradition, "for liberation". On the simplest level, Laurence gives her female protagonist the male part, allowing her to act as epic hero who founds a new order and assumes the powers of Prospero - artist, magician and Shakespeare's figure for himself. Actor, writer and director of her "plot", she attains an authority and authorship which enables her to transmit something of value to the future. But the power of the artist is a resignation to the limits of power, a relinquishing of characteristically "masculine" attributes of rationality and control and an attainment of a difficult humility that comes from involvement with others. Laurence reworks the idea of the artist and paradise to a contemporary feminist perspective: and it is a reworking as significant as Milton's adaptation of classical epic of Christian values, Wordsworth's adaptation of Milton's Paradise Lost to his autobiographical Prelude, or Joyce's adaptation of The Odyssey to his epic of modern life, Ulysses. Unfortunately, however, the parallels with The Tempest also suggest the sense of finality which Laurence expressed elsewhere, a "second sight" which turned out to be all too true, since this was her last novel.' ${ }^{12}$

The descent-line of the artist is patriarchal; it claims that she can write, speak, and be, as a man. But then, like Prospero, she finishes alone. Not yet as different, but a man's equal; her novel is neither an assertion of matrilineality nor a marital happily-ever-after. If all Laurence's men are wounded, a woman who succeeds in resembling them resembles them in that, too.

Like so many other authors in colonies of European expansion, Laurence finds a solution to the racial or ethnic injustices of history in the construction of potentially integrated progeny in the next generation. Her book is a woman's version of the colonialist reading of The Tempest, a reading which was dramatically present in the period. In Laurence the claim that the métis are ancestors introduces a tertium quid, neither Caliban nor Ariel, in which Morag's child is Canada's future, unifying all its pasts. Even at a mere twenty-five-years' distance, this physical 
métissage now appears a period piece, with an optimism which raises a melancholy smile. But the novel is honest enough to show that Morag's daughter appears to be having the same problem her mother had in balancing the claims of love against those of art. The two-city problem was never solved by a marriage.

If we take our reading of Laurence back to Shakespeare, we are encouraged to reread the characters of the play as allegorical directions. To possess the word, to possess the past, depends upon the artist's self-possession, but also upon the artist's willingness to let go. The problem of possession of the island makes one's idea of Caliban replicate one's idea of Prospero, and since Prospero and Miranda have done something very like that, that is, to try to make Caliban more like Prospero, one can see why Caliban himself might aspire to being like Prospero. That is, Caliban does not visualize freedom as something new, but as something which repeats the old, with him replacing Prospero with another master. The return of the oppressed is a reversal. Subsequent misinterpretations of The Tempest have seen Caliban as king of his island, but within the play Caliban has plotted to place Stephano on Prospero's throne. This is not a question, per se, of "colonialism". It might equally be that question of mesure/démesure which is the possession of one's self; to be self-possessed, in the most literal sense. Prospero, after all, never possesses himself more than when he has sacrificed, as he thinks of it, his revenge, his right to revenge, for the forgiveness from which, in some sense, comes a revenge greater (because magnanimous) than mere punishment can be. We cannot imagine Caliban foregoing anything. For Prospero shows himself, in his forgiving gift of his daughter to Alonso's son, the conqueror who out-manœuvres his ostensibly stronger opponent. For two kingdoms he has, like his son-in-law to be, and as his daughter acknowledges over the chess board, played false.

Gloria Naylor was born in New York City in 1950. She won the American Book Award for first fiction in 1983 with The Women of Brewster Place, and is the author of three further novels, Linden Hills (1985), Bailey's Cafe (1992)., and Mama Day, which appeared in $1988^{13}$. Like so many other American authors of the last decade, Naylor turned from public political action, and from the pursuit of social and economic success, to look at the private sphere, and particularly family life. From her first book hers was a confident voice, black, American, female, and ready to take from the inheritance of European literature whatever her ambition required. Linden Hills already used Dante's bolgias to describe a neighbourhood of houses sited on descending crescents of misapplied values down to a hell of empty striving for status at the cost of love ${ }^{14}$. Naylor had and has a message for her black contem-poraries about losing their sense of proportion in the pursuit of golden calves.

If successful adaptation is finding the new in the old, Mama Day succeeds beyond anything that could have been predicted from Naylor's earlier novels. It is an obvious point that plays have no narrators, and can thus present a multivalency which novels struggle to create. Naylor's solution has multiplied her narrators, so that she is able to write from three points of view, and to escape realism. Mama Day is an exceptional blend of what we have come to call magic realism, a story of the 
power of love and hate in which the magic is to be taken as seriously as it is in, say, Malory, who also knows how to preserve mystery by refraining from telling all, who knows when not to explain. Naylor has learned to create a fictional world by multiplying what appear at first to be, but are not, arbitrary details, so that the reader is lulled into apparent recognition, and is not surprised when something reappears with a new meaning, from chickens to broken hearts. The incidents and accidents which Naylor repeats from Shakespeare include dragging characters through the mire and swamp (twice), mutual love at first sight, the strength of hands alone, the book and staff, and, above all, the tempest. There is also a mage; indeed, there may be three. Absences count for something, too : for the first time in fifty years Caliban is silent, and the arguments of colonialism have been left behind.

"Willow Springs" is an island which is not to be found on any map; it is, in some sense, legally nowhere, because not claimed by a state. But it is somewhere off the coast of Georgia and South Carolina; it is pastoral opposed to the city of cities, New York. Unlike many other treatments of The Tempest it takes Gonzalo's commonwealth seriously. But it is matrilineal, matriarchal, and matrilocal. It also takes advantage of certain aspects of inherited African belief, such as whether newborn babies are staying or going, and the importance of giving them a series of names, which help situate part of the culture of the book. The character called Miranda is the eponymous Mama Day, ninety when the book's main action takes place, at least a mid-wife, at most, well, powerful, although one who has never done more than help Nature along. Miranda has never married, and one might be forgiven for thinking that one question implicit in Mama Day is the cost of a great gift, whether it be healing or another art. Miss Miranda has a widowed sister, Abigail, whose grand-daughter, Cocoa, or Ophelia, is the sisters', and the book's, plot-centre.

The thematic centres are love, hate, and jealousy, not in this generation only, in which Cocoa/Ophelia loves, marries, and struggles to live well with George Andrews, but there is a richly evoked depth to questions about inheritance, and about what might happen between men and women in any generation. There is nothing particularly articulate about Ophelia, despite her Shakespearean name which, in the book's poetic economy, ties her to water ${ }^{15}$. She is no poet, no intellectual, no artist. When she refers to Shakespeare it is to write him off : "Just proves that Shakespeare didn't have a bit of soul - I don't care if he did write about Othello, Cleopatra, and some slave on a Caribbean island" (p. 64).

It would be a mistake to look for simple correspondances. Mama Day is not about freedom, but about learning to live with love, and all the giving, and giving up, which that implies. There is, for once, no Caliban. Dr Buzzard, gambler, distiller, and retailer of charms and potions, may suggest a parody of the salvage and deformed Caliban. But when one knows that his real name is Rainbow Simpson, his bedrock goodness is clear. Storms inform many of the characters. And, on a metaphorical level, all that Dr Buzzard does is make "moonshine", which is also known as "white lightning". He is a renowned poker player, renowned not because of his magic, but because he cheats. 
George is not Ferdinand. Nevertheless, his love and the strength of his bare hands are one of the transformations of the play, compressing and rearranging Prospero's farewell. George loves Shakespeare, and is particularly fond of Lear because it features a bastard - which suggests that he is not the best of readers. He is also passionate about American football. But George is an ordinary meat and potatoes man, a successful engineer who is partner in a small firm of designers. He cannot believe in the island's strange noises. Characters not there speak; if unseen voices constitute an Ariel, then there is an equivalence, but it is not a necessary one. Ruby, the villain of the piece, is not Sycorax. Yet she has grown so fat as hardly to be able to move, so jealous of her much younger husband that no younger woman is safe from her ${ }^{16}$. Miranda acknowledges more than once that nothing is so powerful as hate. One might say that Ruby had grown into a hoop; she is certainly already a tyrant when we meet her.

Shakespeare's play begins with a tempest in which we believe at least for one scene, before Prospero assures Miranda that it is not real. Naylor's tempest is a hurricane which cuts the island off from the mainland. As a consequence Mama Day finds a book and a staff, but it is not she who uses them. It would be wrong of me to reveal all, and that is not the point of my exposition. Normally one would smile at the arbitrary recycling of incidents and accidents of the older work, but in the case of such a successful reinterpretation one might be forgiven for not realizing that props which are completely integrated in the action are also allusions. I suspect that many of the book's enthusiastic readers have been ignorant of the breadth and depth of the Shakespeare allusions.

Does it matter? Yes, it does, because if we take Naylor's interpretation back to Shakespeare, we can see that she has emphasized life after marriage. She has moved beyond the traditional reading of Prospero as Shakespeare's autobiographical meditation on his art, which has been so important to the legitimacy of self-styled marginal writers, and just ignored the current critical arguments over Shakespeare's colonialism. One is tempted to categorize her emphasis on universals like the measure of human emotion as a reassertion of a conservative Shakespeare. It is, nonetheless, undeniable that hers is an original reading which does a great deal more than simply reverse Shakespeare's perceived categories.

The generation which separates Margaret Laurence, the white Canadian, from Gloria Naylor, the Black American, suggests more differences than race and nationality. One is prone to forget just how great were the social changes after the last war, from which Naylor's generation benefited, for all her reservations about what happens when women allow ambition to over-ride the values of love, home, and family. Laurence had a strong personal pessimism about the possibility of reconciling work, high expectations about companionate marriage, and childrearing. Naylor, who conceptualizes a strong matriarchal tradition, and thus a society rather different from Laurence's, nevertheless shares Laurence's fear, but sees possibilities of mutual respect. Naylor's pessimism, if one may call it that, belongs to America of the eighties, with its extraordinary retreat from political action into a degree of conservatism with which the literature of the last decade has 
been strongly marked. Her book is a reminder that magic realism is a style, one which can as easily be used for apolitical as for committed writing.

One has to ask, when dealing with intertextuality, what the old text has been used for, and impoverished how the new text would be without it. A reader innocent of colonialist interpretations of The Tempest, or of the central traditions of Caliban and language, Prospero and artistic power, would read Laurence less allegorically, certainly. But it is also part of the strength of a new interpretation that it stands on its own, that the themes of The Diviners are clear from the novel alone. True as that seems, when one looks at Naylor's delight in rewriting some of Shakespeare's arbitrary incidents, one is tempted to contradict that assertion, for part of the pleasure of her book depends upon our appreciation of her allusions. What little the innocent reader would lose would be very precious. In both case the very existence of the conversation between the authors is an assertion of integration as well as staking a claim.

If the "happy wrack" poses questions about finding oneself, about righting wrongs, about possession and possessions, about letting go, it has also posed questions about power and poetry which have made the play central for writers and artists of many different kinds. This has been so since the seventeenth century, and in the Purcell year we are more than ever aware of the strange yet familiar familial balance first created in the Dryden/Davenant/Shadwell semi-opera. The self one possesses is not one's self only, and both Laurence and Naylor emphasize their protagonists as inheritors and progenitors. The creative writer who proceeds by binary opposition, by parallel and variation, by juxtaposition and paradox, works in ways that expository criticism cannot equal. One might say she holds the mirror up to Culture, and gives us also an imitation of Art.

Ruth MORSE

Université de Paris-VII

1 Studied in detail by Mary Margaret Nilan, The Stage History of The Tempest: A Question of Theatricality, Northwestern U. unpubl. Ph.D., 1967; University Microfilms 1980. The imitations in the Fletcher/Middleton Double Marriage (161923) or Suckling's The Goblins (1637-40) would also repay study.

2 2 See the arguments not only of Ashcroft, Griffiths, and Tiffin in their groundbreaking The Empire Writes Back (London, Routledge, New Accents, 1989), but those of Edward Said in, above all, Culture and Imperialism (London, Chatto, 1993). Some of the problems raised in this work are discussed in my "Orientalism : Edward Said's Imperialism as Culture", The Cambridge Review, October 1993, pp. 115-19. In the specialist sense, see Brian Vickers, Appropriating Shakespeare: Contemporary Critical Quarrels, New Haven and London, Yale U. P., 1993. 
3 In addition to Aldous Huxley's Brave New World, there are, for example, Phyllis Gottleib, O Master Caliban (N.Y., Harper and Row, 1976), Stephen Popkes, Caliban Landing (N.Y., Congden and Weed, 1987); J.G. Ballard has repeatedly returned to Prospero and his island. Tad Williams's Caliban's Hour (London, Legend, 1994), is an example of an established science fiction author moving, through "science fantasy", to something more traditional, a fantasy of rejection and redemption (Miranda's daughter marries Caliban not only to save her mother, but to escape a more conventional arrangement) entirely without merit.

4 The well-known Hispanic authors Rodo and Fernandez Retamar had a strong initiating influence, but Aimé Césaire belongs here, too.

5 As Stephen Orgel puts it, the play is supremely concerned with "the nature of authority and power; the conflicting claims of vengeance and forgiveness, of justice and mercy; the realities of reconciliation and the possibility of regeneration", quoted from the Introduction to his edition (Oxford, 1987). Further citations from the play will be from this text.

6 Margaret Atwood's Surfacing and Marina Warner's Indigo, to name but two. Omissions will be repaired in a longer work, tentatively entitled Tempests : After Shakespeare.

7 In this, Marlowe's use provides an instructive contrast: "measure" usually appears in contexts which discuss ambition in terms of the size of the universe, so "measure" appears most in Tamburlaine.

$8 \quad$ The Sea and the Mirror (London, 1942).

9 Orgel's pessimisim about Shakespeare's attitudes to women, already hinted at in "Prospero's Wife" in Representations 8 (1984), pp. 1-13, at moments amounts to misogyny, and is something I should wish to deal with in the future.

10 Jonathan Bate, "Caliban and Ariel Write Back" Shakespeare Survey 48 (1995), pp. 155-62.

11 Originally published in New York by Knopf and now republished by Virago. Quotations are from the Canadian Bantam paperback of 1984. 
12 "Margaret Laurence's The Diviners: The Uses of the Past", in Critical Approaches to the Fiction of Margaret Laurence, ed. Colin Nicholson (London, Macmillan, 1990), pp. 200-1.

13 Originally published by Ticknor and Fields, a "quality" division of Houghton Mifflin, the book is now published by Random House's Vintage paperbacks, and it is from the Vintage Contemporaries reprint of 1993 that I quote.

14 Part of Naylor's epic ambition, like Laurence's for Manawaka, is to tie her novels together by cross-reference. Unfortunately, these inner references sometimes creak when a later conception of a character contradicts what may have been its earliest inception. "And she remembered being so ashamed of her great-aunt, Miranda Day, when she pulled up in that cab each summer, calling from the curb at the top of her voice, 'Y'all better be home. Mama Day done come to visit a spell with her Northern folks.' Coming with her cardboard suitcases, loose-fitting shoes, and sticky jars of canned whatever. Toothless, but ready with a broad grin; almost illiterate but determined to give her very loud opinion regardless of the subject or the company" (p.147). This stereotypical mammy has nothing of Mama Day's dignity and fire.

15 The name is not only an allusion to water; it also asks us to think about a family - and lover — who are supportive.

16 The reference to Shakespeare's witch comes from Ophelia in a different context, another instance of Naylor's dispersals : "I couldn't forget how quickly we'd gotten married. It's as if we didn't dare to stop and think. But I was thinking now. And I wanted us to work so badly that I would be tempted to try and squeeze myself up into whatever shape you had calculated would fit into your plans. How long could I do it? The answer scared the hell out of me : I could have done it forever. You start out feeling a little uncomfortable, but then when you look around that's the shape you've grown into" (p. 146). 